\title{
Hardfacing by Plasma Transferred Arc Process
}

\author{
Víctor Vergara Díaz ${ }^{1}$ Jair Carlos Dutra ${ }^{2}$ and Ana Sofia Climaco D'Oliveira ${ }^{3}$ \\ ${ }^{1}$ University of Antofagasta, Mechanical Engineering Department \\ ${ }_{2}^{2}$ University Federal de Santa Catarina, Mechanical Engineering Department \\ 3 University Federal do Paraná, Mechanical Engineering Department \\ ${ }^{1}$ Chile \\ 2,3 Brasil
}

\section{Introduction}

According to the literature, the plasma transferred arc welding process which employs the filler metal in wire form is known as Plasma Arc Welding (PAW) while that which employs powder filler material is generally referred to as Plasma Transferred Arc (PTA), Dai et al., 2008.

The PTA process can be considered a derivation of the PAW process. The similarities between the two processes can be observed in Figure 1. Both welding processes employ a non-consumable tungsten electrode located inside the torch, a water-cooled constrictor nozzle, shield gas for the protection of the molten pool, and the plasma gas. The difference between the two welding processes lies in the nature of the filler material, powder instead of wire, which requires a gas for its transport to the arc region. The diagram in Figure 1 shows the two processes with their differences and similarities.

The equipment required to carry out the deposition through the PTA plasma process is very similar to that used in PAW. When PAW is employed the equipment must be able to drive spooled wires of various gages and different materials, at constant or pulsed velocities. In the PTA plasma welding process, the filler material is used in the form of a powder, and specific powder feeding equipment is required to transport it to the voltaic arc to produce the coating. With respect to its application for coating, the PTA process is appropriate since it produces dilution values of the order of 6 to $10 \%$ (Gatto, et al., 2009), much lower than those obtained with other arc soldering process which are around 20 to $25 \%$. The low distortion, the small zone affected by the heat and the refined microstructure are also features of this technique (Zhang, et al., 2008; Liu, et al., 2008).

In the PTA and PAW processes an inert gas is used as the plasma gas, which is forced to pass through the orifice of the constrictor nozzle, where the electrode is concentrically fixed. The shield gas passes through an external opening, concentric to the constrictor nozzle, effectively protecting the weld against contamination from atmospheric air (active or inert). On the other hand, in the PTA process a carrier gas is used to transport the filler material through flexible tubes to the constrictor nozzle, allowing its entrance into the plasma arc in a convergent form. The gas used for this purpose is generally argon. 


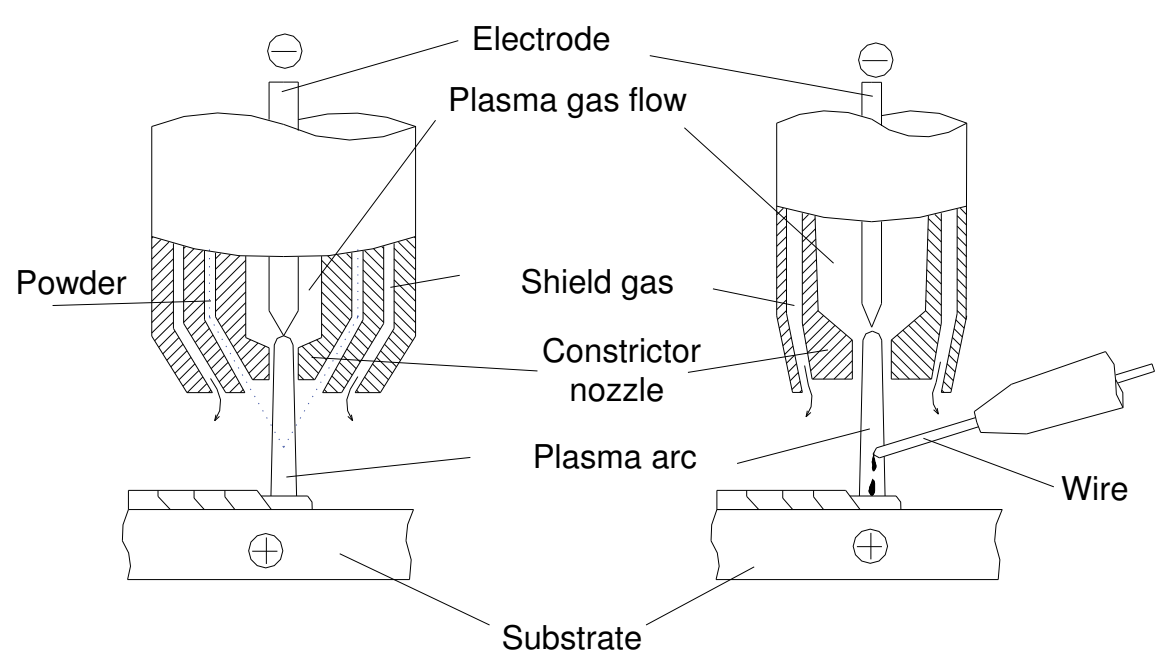

\section{PTA PROCESS}

PAW PROCESS

Fig. 1. Comparison of Plasma Transferred Arc processes PTA and PAW.

Given that the tungsten electrode lies within the constrictor nozzle of the welding torch, it is difficult to open the arc by contact, and thus equipment called a plasma module must be used to establish the arc opening. An electronic igniter provides voltage peaks between the tungsten electrode and constrictor nozzle, generating a small spark in this region. Thus, with the passage of the plasma gas a low intensity electric arc appears between the tungsten electrode and constrictor nozzle, called the pilot arc (non-transferred arc). The pilot arc forms a pathway of low electrical resistance between the tungsten electrode and the workpiece to be welded facilitating the establishment of the main arc when a power source is added.

In practice, the parameters which control the quality of the weld are the rate at which the material is added, the gas flow rate (shield gas, plasma gas, carrier gas), the weld current, the nozzle to workpiece distance (see below) and the welding speed.

The basic configuration of the constrictor nozzle is shown in Figure 2, where the parameters employed in the process are indicated. The distance from the external face of the constrictor nozzle to the substrate is called the nozzle to workpiece distance (NWD).

The recess $(\mathrm{Rc})$ of the electrode is measured from the electrode tip to the external face of the constrictor nozzle. Alterations in the arc characteristics are influenced by this factor, which defines the degree of constriction and the rigidity of the plasma jet (Oliveira, 2001).

Oliveira (2001) studied the influence of the electrode recess of the plasma transferred arc process fed by wire in order to identify whether the degree of arc constriction influences the arc voltage. The results showed that, on average, a $2.4 \mathrm{~V} / \mathrm{mm}$ variation in the voltage occurred as a function of the electrode recess. 


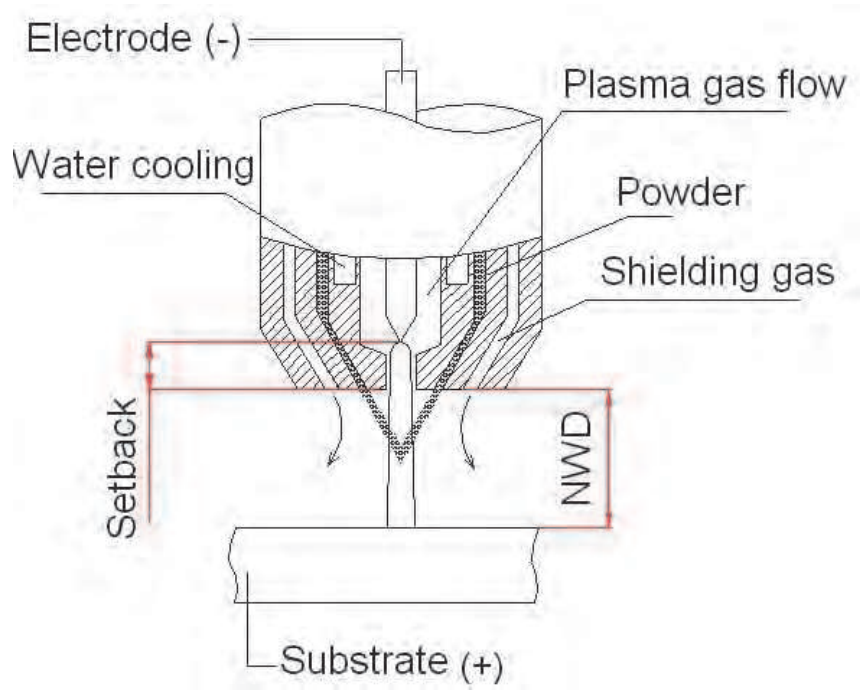

Fig. 2. Nozzle to workpiece distance (NWD) and electrode setback (Rc) (Vergara, 2005).

In general, the maximum and minimum values for the adjustment of the electrode recess vary according to the welding torch. The electrode recess of the welding torch PWM-300, manufactured by Thermal Dynamics Corporation, for instance, has a range of adjustment of 0.8 to $2.4 \mathrm{~mm}$.

As the electrode recess is reduced, the weld bead width increases and weld beads with lower penetration depth are obtained. This variation in the geometric characteristics of the weld bead is due to a reduction in the constriction effect producing a larger area of incidence of the arc on the substrate.

The constrictor nozzle (made of copper), where the electrode is confined, has a central orifice through which the arc and all of the plasma gas volume pass. The diameter of the orifice of the constrictor nozzle has a great influence on the quality of the coating since this relationship is directly related to the width and penetration of the weld bead produced. An insufficient plasma gas flow rate affects the useful life of the constrictor nozzle since it leads to its wear. The weld current reduces as a function of the decrease in the diameter of the constricting orifice, due to an increase in the weld arc temperature.

The extent to which the nozzle to workpiece distance influences the coating is strongly dependent on the electrode recess in relation to the constrictor nozzle and the diameter of the constrictor orifice. The larger the electrode recess adopted and the smaller the constrictor orifice diameter the greater the effect of the arc constriction, making it more concentrated.

In the "melt-in" technique small electrode recess values are used, the arc being submitted to a low degree of collimation, assuming a conical form. In this situation, a variation in the nozzle to workpiece distance, even within normal limits, results in a change in the characteristics of the weld bead, in the same way as occurs in the GTAW process. Thus, the greater the nozzle to workpiece distance the lower the penetration and wider the width of the weld bead due to the increase in the area of incidence of the arc on the substrate. 
Hallen et al. (1991) reported that to obtain a good deposition yield, the nozzle to workpiece distance should not be greater than 10 to $15 \mathrm{~mm}$. At values higher than this range the efficiency of the shield gas is significantly reduced.

The authors of this paper have also reported results in relation to the nozzle to workpiece distance, for two values: 15 and $20 \mathrm{~mm}$. The study showed that as the nozzle to workpiece distance increases the degree of dilution decreases.

The general objective of this study was to investigate the PAW and PTA welding processes with a view to their application in surface coating operations, particularly on hydraulic turbine blades worn by cavitation. This research was motivated by the observation that information is scare in relation to the benefits offered by the plasma welding process using powder instead of wire filler material in the application of coatings. The geometric characteristics of the weld beads, degree of dilution, hardness and microstructure were evaluated.

\section{Materials and Methods}

\subsection{Test bench}

Initially, a test bench was assembled based on equipment previously developed at LABSOLDA (Oliveira, 2001; Vergara, 2005) which allowed tests to be carried out on the plasma transferred arc welding process fed by wire. On the same test bench, a similar process fed by powder was assembled. The welding source was equipment which, via an interface, was connected to a PC. By way of a very versatile software program almost all of the process variables could be controlled.

Of the three gas circuits, that which received most attention was the plasma gas given its considerable relevance in terms of the quality of the deposits. A mass flow controller was used, in which the control is carried out electronically and the command signal is a reference voltage. The other gas flow circuits are simply monitored by electronic flow meters, however these are volumetric.

One of the fundamental parts of the equipment is the device known as the plasma module, which enables any version of plasma welding to be carried out based on conventional welding sources for GTAW or coated electrode. For the displacement of the welding torch an electronic device (Tartílope) was used. The system component which was integrally designed for this specific development was the powder feeding device, which functions through a combination of an endless screw and a gas flow as the powder carrying mechanisms. The weld torch was developed based on the plasma torch for keyhole welding. The great advantage of this lies in its multiprocess aspect which allows it to work with plasma employing powder or with conventional plasma. Also, the design adaptation allows the use of constrictor nozzles with different angles of convergence for the powder feeding. Initially, analysis was carried out on the torches to be used in this research. It was observed that the PTA torch had a nozzle with a constrictor diameter of $4.8 \mathrm{~mm}$. In the case of the PAW torch, the manufacturer provides three nozzles with constrictor diameters of 2.4, 2.8 and $3.2 \mathrm{~mm}$, which are designed according to the welding current to be applied.

In this case, the nozzle with the largest constrictor diameter available for the PAW torch was selected, that is, $3.2 \mathrm{~mm}$.

Figure 3 shows a general view of the equipment developed, that which forms part of the test bench for the PAW and PTA welding processes being shown in the upper part of the figure. 
In this study argon with a purity of $99.99 \%$ was used as the plasma, shield and carrier gases. A tungsten electrode with $2 \%$ thorium oxide (EWTh-2) and with a diameter of 4.8 $\mathrm{mm}$ was used. The angle of the electrode tip was maintained at $30^{\circ}$ for all of the experiments.

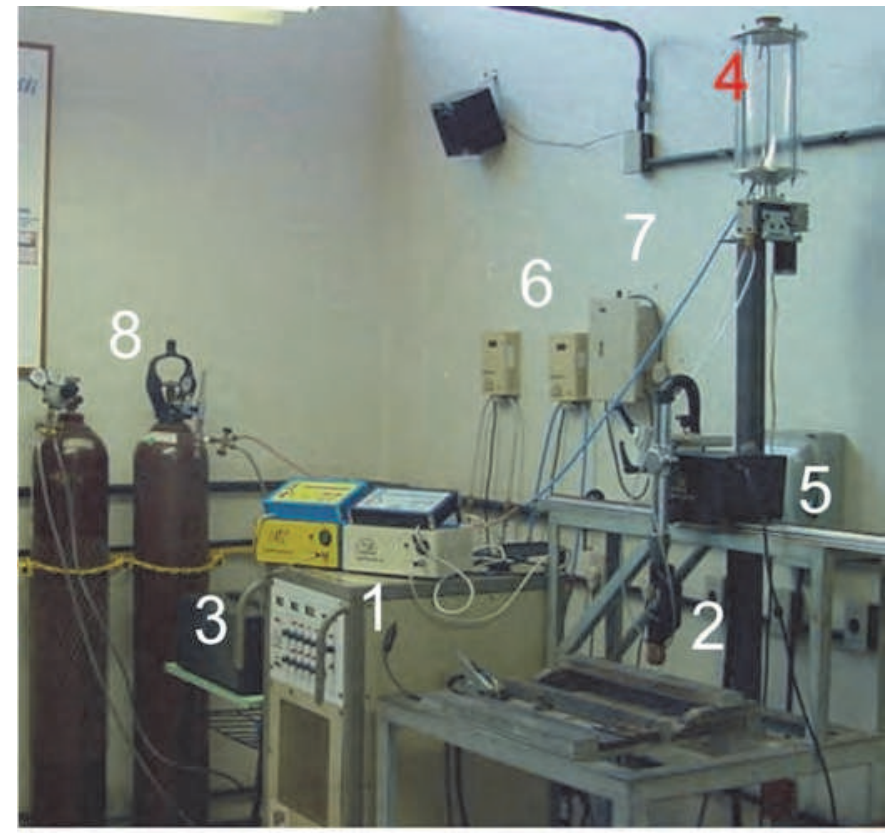

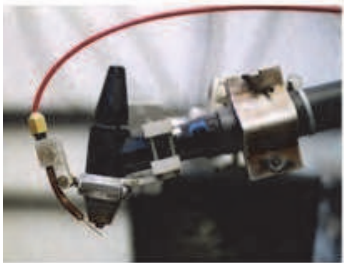

Adapted PAW torch

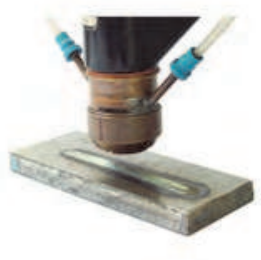

Adapted PTA torch

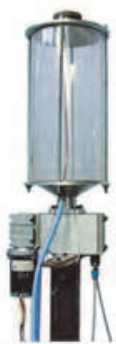

PTA Powder Feeder

Fig. 3. Test bench assembled at the welding laboratory. 1-Welding source; 2-Adapted plasma torch; 3-Plasma module; 4-Powder feeder; 5-Torch displacement system; 6-Digital gas meters; 7-Electronic gas valve; 8-Gases

\subsection{Constrictor nozzle in PTA process}

The configuration of the constrictor nozzle developed in this study included two conduits for the passage of the carrier gas, the role of which is to feed the powder to the plasma arc in a convergent form. Figure 4 shows a cross-section of the constrictor nozzle. At $60^{\circ}$ the constrictor nozzle allows the entrance of powder directly into the molten pool, when a nozzle to workpiece distance of $10 \mathrm{~mm}$ is used. 


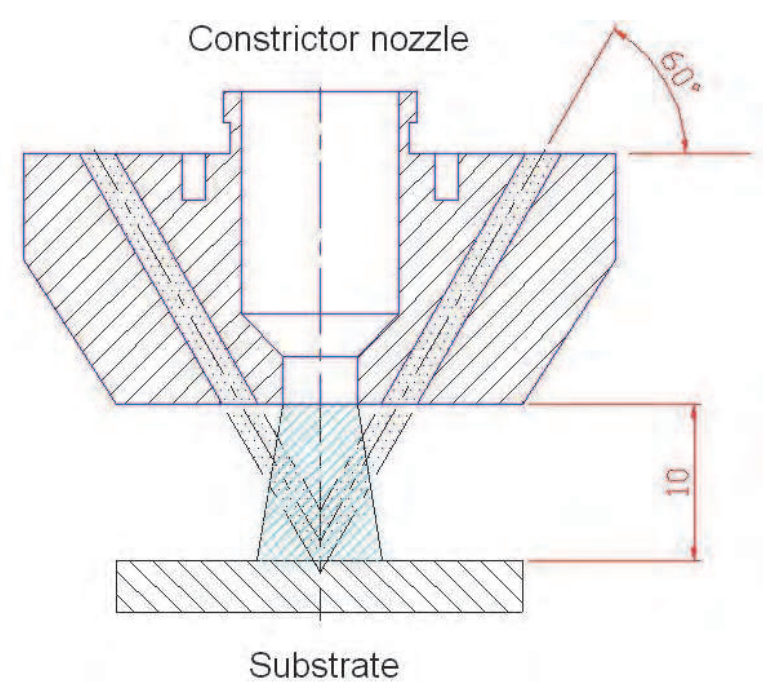

Fig. 4. Cross-section of constrictor nozzle showing the entrance of the powder flow into the plasma arc. (Vergara, 2005).

\subsection{Characterization}

Deposits of the atomized alloy Stellite 6, Figure 5, were processed on carbon steel plates (class ABNT 1020; dimensions $12.5 \times 60 \times 155 \mathrm{~mm}$ ), using a constant continuous current. Table 1 shows the chemical composition of the substrate. The chemical analysis of the different filler materials was carried out by optical emission spectrometry and the results are shown in Tables 2 and 3.

Single weld beads were deposited with the parameters indicated in Table 4 and samples were removed for their characterization. This table gives the operational parameters for the PTA and PAW plasma welding processes, in which there are parameters which could not remain constant in the two process, for example: nature of the filler material (in PAW wire and in PTA powder); wire speed (not required in PTA); carrier gas (not required in PAW); constrictor nozzle diameter (in PTA $4.8 \mathrm{~mm}$ and in PAW $3.2 \mathrm{~mm}$ ).

Initially, the weld beads were submitted to visual inspection for the presence of welding defects, the degree of dilution was determined by the areas method using micrographs of the cross-sections of the deposits, etched with 6\% nital. Profiles of the Vickers microhardness, with a load of $500 \mathrm{~g}$, enabled the evaluation of the uniformity of the weld beads processed, according to the procedure of the standard ABNT6672/81. The determination of the microhardness profiles, average of three measurements, was carried out at the center of the weld beads and in the region where they overlap. To determine the microstructure by optical microscopy a cross-section was prepared following standard procedures, the microstructure being revealed after electrolytic attack with oxalic acid. 


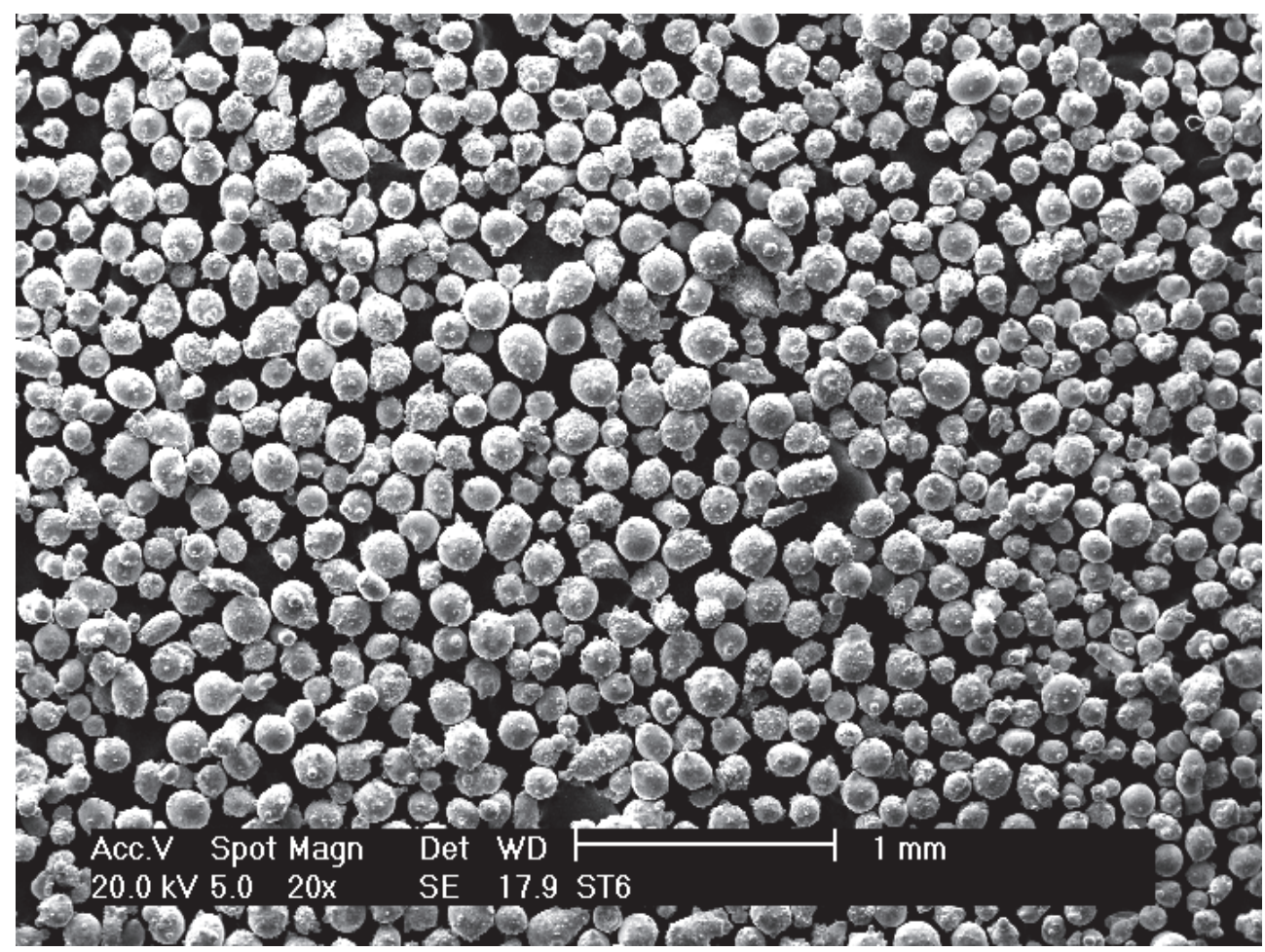

Fig. 5. Morphology of powder deposited by the PTA process (Stellite 6).

\begin{tabular}{|c|c|c|c|c|c|c|c|c|}
\hline C & Si & Mn & $\mathbf{P}$ & $S$ & $\mathrm{Cr}$ & Mo & $\mathbf{N i}$ & Al \\
\hline 0.11 & 0.22 & 0.74 & 0.021 & 0.008 & 0.027 & 0.024 & 0.011 & 0.06 \\
\hline $\mathrm{Cu}$ & $\mathbf{V}$ & $\mathbf{W}$ & Sn & Fe & & & & \\
\hline 0.016 & 0.015 & 0.026 & 0.065 & 98.6 & & & & \\
\hline
\end{tabular}

Thickness: $12.7 \mathrm{~mm}$

Table 1. Chemical composition of the low carbon steel substrate.

\begin{tabular}{l|l|l|l|l|l|l|l|l}
\hline $\mathbf{C}$ & $\mathbf{S i}$ & $\mathbf{M n}$ & $\mathbf{C r}$ & $\mathbf{M o}$ & $\mathbf{N i}$ & Co & W & Fe \\
\hline 1.32 & 1.30 & 0.028 & 30.01 & 0.24 & 2.45 & Bal & 5.21 & 2.05 \\
\hline
\end{tabular}

Hardness: 38-47 Rc; Particle size: 45 to $150 \mu \mathrm{m}$; Density: $8.3 \mathrm{~g} / \mathrm{cm}^{3}$

Table 2. Chemical composition of the filler material Stellite 6 in the form of a powder (BT906)

\begin{tabular}{l|l|l|l|l|l|l|l|l}
\hline $\mathbf{C}$ & $\mathbf{S i}$ & $\mathbf{M n}$ & $\mathbf{C r}$ & $\mathbf{M o}$ & $\mathbf{N i}$ & Co & W & Fe \\
\hline $0.9-1.4$ & 2.0 & 1.0 & $26-32$ & 1.0 & 3.0 & Bal & $3.0-6.0$ & 2.0 \\
\hline
\end{tabular}

Table 3. Chemical composition of filler material Stellite 6 in the form of steel (BT-906T). 


\begin{tabular}{l|c|c}
\hline \multicolumn{2}{c}{ PTA Process } & \\
\hline Welding current & $\mathrm{A}$ & 160 \\
Welding speed & $\mathrm{cm} / \mathrm{min}$ & 20 \\
Plasma gas flow rate & $1 / \mathrm{min}$ & $2.2 ; 2.4 ; 3.0$ \\
Shield gas & $1 / \mathrm{min}$ & 10 \\
Carrier gas & $1 / \mathrm{min}$ & 2 \\
Feed rate & $\mathrm{kg} / \mathrm{h}$ & 1.4 \\
Constrictor nozzle diameter/ convergence & $\mathrm{mm} /{ }^{\mathrm{o}}$ & $4.8 / 30$ \\
angle & $\mathrm{mm}$ & 10 \\
Nozzle to workpiece distance & $\mathrm{mm}$ & 2.4 \\
Setback & & \\
\hline \multicolumn{2}{c}{ PAW Process } & \\
Wire diameter (tubular) & $\mathrm{mm}$ & 1.2 \\
Wire speed & $\mathrm{m} / \mathrm{min}$ & 3.0 \\
Deposition rate & $\mathrm{kg} / \mathrm{h}$ & 1.4 \\
Constrictor nozzle diameter & $\mathrm{mm}$ & 3.2 \\
\hline Welding current & $\mathrm{A}$ & 160 \\
Welding speed & $\mathrm{cm} / \mathrm{min}$ & 20 \\
Plasma gas flow rate & $1 / \mathrm{min}$ & $2.2 ; 2.4 ; 3.0$ \\
Shield gas & $1 / \mathrm{min}$ & 10 \\
Feed rate & $\mathrm{kg} / \mathrm{h}$ & 1.4 \\
Nozzle to workpiece distance & $\mathrm{mm}$ & 10 \\
Setback & $\mathrm{mm}$ & 2.4 \\
\hline
\end{tabular}

Table 4 . Welding variables and parameters.

\section{Results and discussion}

\subsection{General characteristics}

Figure 6 shows the external aspect of the beads where significant differences between them can be observed. The PTA process produced a better surface finish, better dilution, better wetting and wider width.

Figures 7 and 8 show cross-sections of the beads obtained using the two processes (PAW and PTA) where considerable differences in the penetration profile of the welds can be noted and Figure 9 shows the results for the geometric parameters of the beads, for the three levels of plasma gas flow rate tested in this study: 2.2; 2.4 and $3.01 / \mathrm{min}$. On comparing the deposits obtained from the two processes it can be observed that the reinforcement and the penetration are always smaller in the PTA process (Figure 9). In the PTA process there was a significantly wider cord width, which is due to the use of a constrictor nozzle with a wider diameter.

The data shown in Figure 9 together with an analysis of the variance in Tables 5, 6 and 7, indicate that the welding process and plasma gas flow rate have significant effects on the geometric parameters of the bead.

In relation to the convexity index $(C I=100 * \mathrm{r} / \mathrm{W})$, Silva et al. (2000) establishes that values close to $30 \%$ are desirable for the relation between the width (W) and reinforcement (r) of the weld bead. Figure 10 shows the convexity index of the weld bead for the PAW and PTA processes as a function of the plasma gas flow rate. 
Analysis of Figure 10 shows that for the three plasma gas flow rates tested the PTA process provided acceptable convexity of the weld beads (less than $30 \%$ ), a highly desirable condition. In the case of the PAW process, the convexity index was acceptable only for low plasma gas flow rates.

The average values for the areas of the metal deposited varied for the two welding processes studied, as expected, due to the difference in the diameters of the constriction orifices used in each case and the material loss according to the efficiency of the deposition process.

Figure 11 shows that in the PTA process there was loss of material. Lin (1999) observed that losses occur mainly due to vaporization and also dispersion of the particles after making contact with the substrate.

Vergara (2005), reports that the carrier gas flow rate influences the dispersion of the particles. In many cases it is possible, at the end of the finishing operation, to observe unmolten powder particles adhered to the sides of the finish. On the other hand, when the deposition rate is very high $(1.5 \mathrm{~kg} / \mathrm{h})$ in relation to the welding current $(160 \mathrm{~A})$ unmolten power can be seen spread over the substrate. Vergara [9] observed that the PTA process has a deposition efficiency of the order of $87 \%$ when a constrictor nozzle of $30^{\circ}$ is used. Similar results have been reported by Davis (1993), who demonstrated a range of 85 to $95 \%$ deposition yield for the PTA process.

The graph in Figure 12 shows the effect of the plasma gas flow rate on the degree of dilution using the wire Stellite $6,1.2 \mathrm{~mm}$ tubular diameter. The results indicate that the dilution increases with the plasma gas flow rate possibly due to the greater pressure of the plasma jet. Similar results were found for the PTA process, with dilution values being lower than those achieved with the PAW process, as expected, due to the difference in the diameters of the constrictor orifice. Vergara (2005) reports that the diameter of the constrictor nozzle orifice has a considerable influence on the quality of the finish since it is directly related to the width and penetration of the weld bead produced. The data in Figure 12 together with the analysis of variance in Table 8 indicate that, in general, the welding process and the plasma gas flow rate significantly affect the dilution. Similar conclusions have been reported by Silvério (2003) for the alloy Stellite 1.

The good results obtained for the PTA process are associated with:

- Wider weld beads $\Rightarrow$ greater area of covering

- $\quad$ Lower dilution $\Rightarrow$ deposits with composition closer to that of the filler alloy

- Better wetting, lower convexity $\Rightarrow$ reduced risk of lack of penetration/ fusion between weld beads.

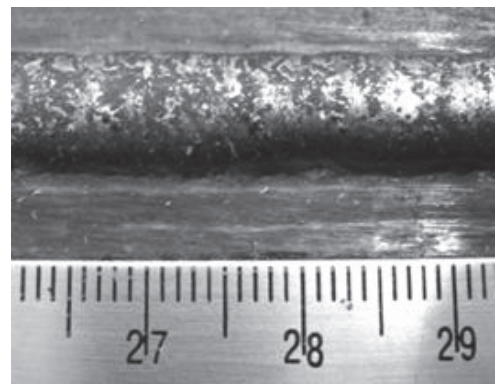

a) PAW

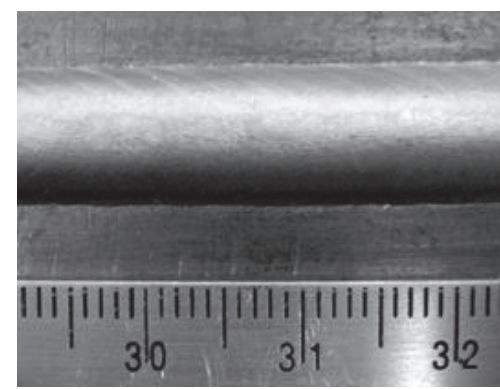

b) PTA

Fig. 6. Superficial aspect of Stellite 6 deposited by: a) PAW and b) PTA. Welding current $=$ $160 \mathrm{~A}$, Welding speed $=20 \mathrm{~cm} / \mathrm{min}$, Feed rate $=1.4 \mathrm{~kg} / \mathrm{h}$, Plasma gas flow rate $=2.4 \mathrm{l} / \mathrm{min}$. 


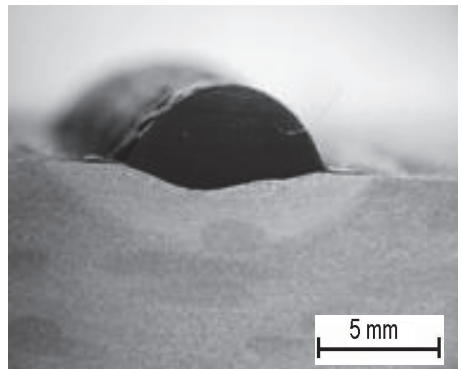

(a)

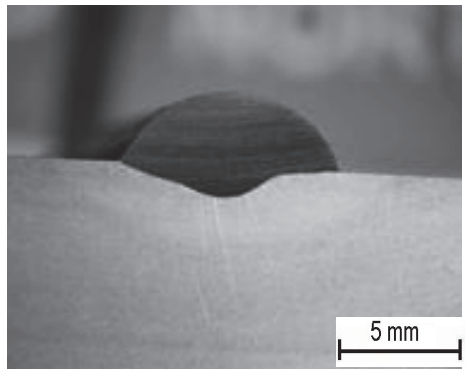

(b)

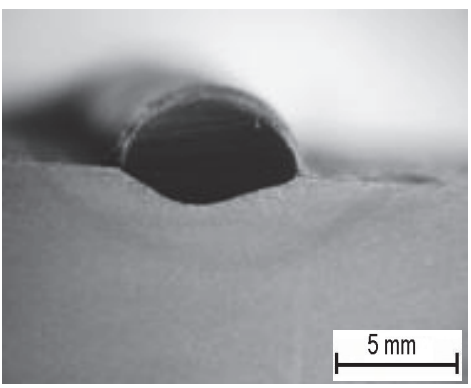

(c)

Fig. 7. Cross-section of weld beads processed via PAW. Plasma gas flow rate: (a) 2.2 (l/min); (b) 2.4 (1/ min); and (c) $3.0(1 / \mathrm{min})$

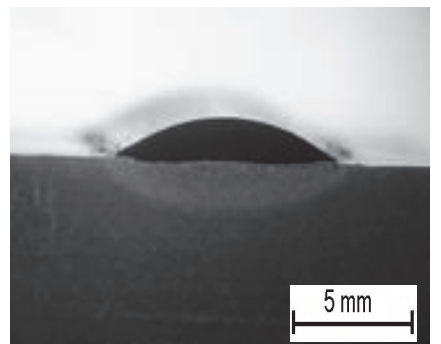

(a)

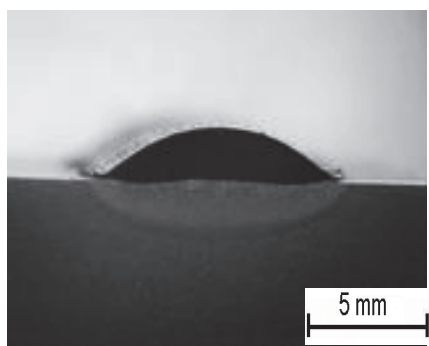

(b)

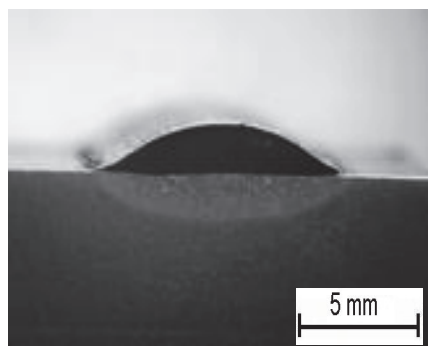

Fig. 8. Cross-section of weld beads processed via PTA. Plasma gas flow rate: (a) 2.2 (1/ min); (b) 2.4 (l/ $\mathrm{min})$; and (c) 3.0 (l/ $\mathrm{min})$. 


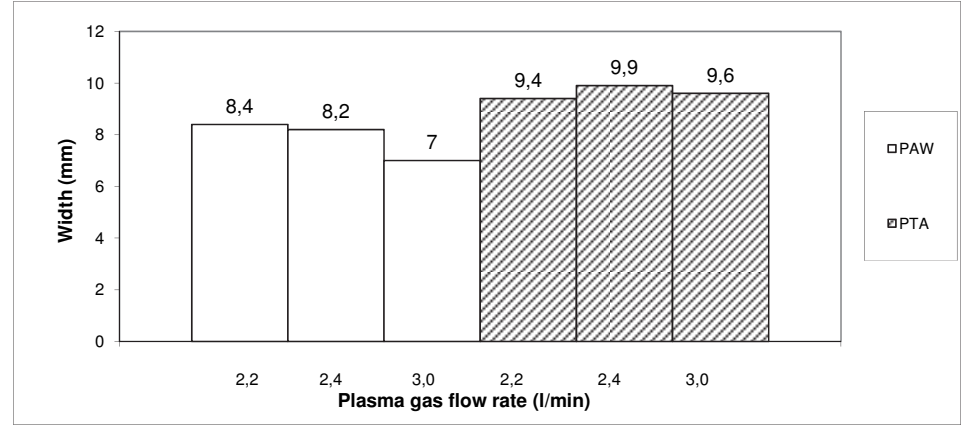

a) Width

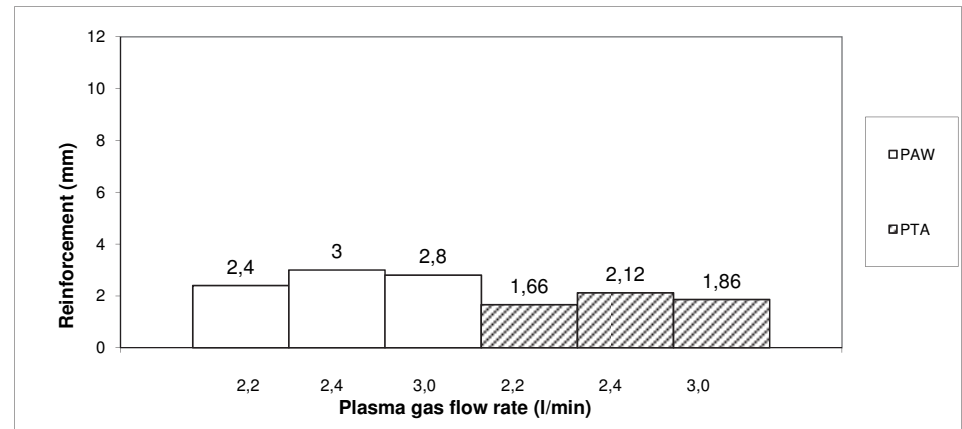

b) Reinforcement

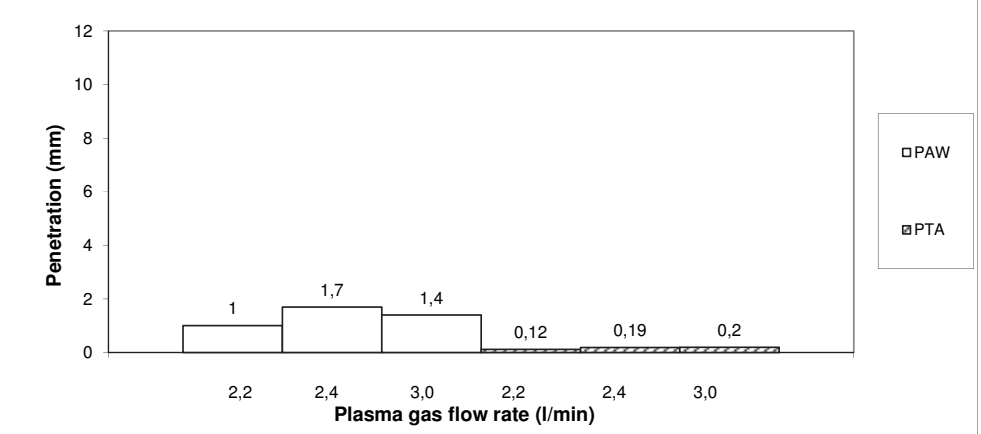

c) Penetration

Fig. 9. Effect of plasma gas flow rate on geometric parameters (Width, reinforcement, penetration). 


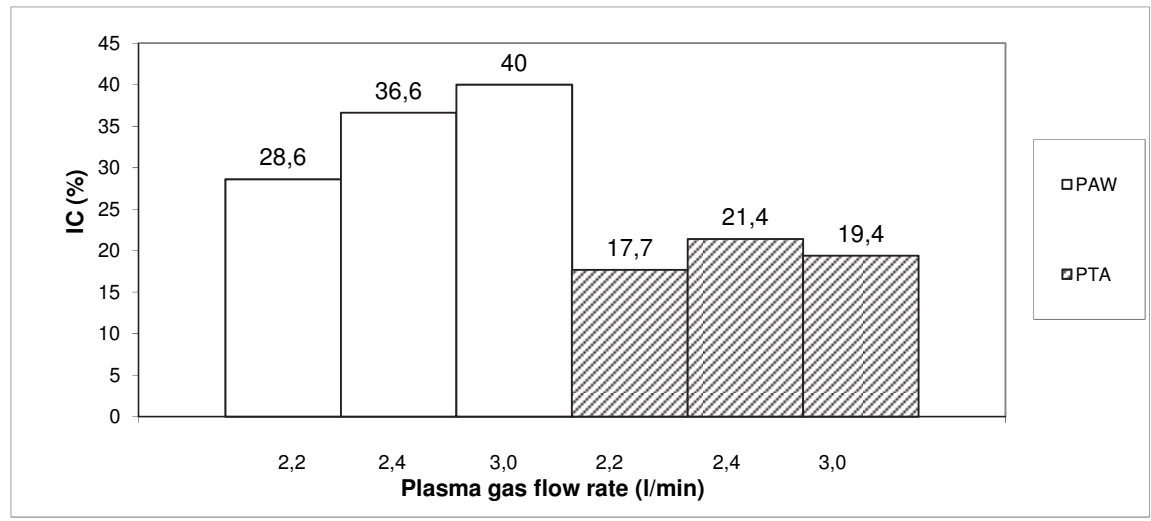

Fig. 10. Effect of plasma gas flow rate on convexity index.

\begin{tabular}{lccccc}
\hline Source of variation & $\begin{array}{c}\text { Sum of } \\
\text { squares }\end{array}$ & $\begin{array}{c}\text { Degrees of } \\
\text { freedom }\end{array}$ & $\begin{array}{c}\text { Average of } \\
\text { squares }\end{array}$ & Fobserved & F critical \\
\hline Welding process & 17.85 & 1 & 17.85 & 1444.35 & \\
Plasma gas flow rate & 2.316 & 2 & 1.16 & 93.67 & \\
Interaction & 2.33 & 2 & 1.16 & $94.14>$ & 3.55 \\
Residual & 0.22 & 18 & 0.0124 & & \\
& & & & & \\
Total & 22.72 & 23 & & & \\
\hline
\end{tabular}

Obs.: Index of significance $(\alpha)=5 \%$

Table 5. Results of the analysis of variance for width.

\begin{tabular}{lccccc}
\hline Source of variation & $\begin{array}{c}\text { Sum of } \\
\text { squares }\end{array}$ & $\begin{array}{c}\text { Degrees of } \\
\text { freedom }\end{array}$ & $\begin{array}{c}\text { Average of } \\
\text { squares }\end{array}$ & Fobserved & F critical \\
\hline Welding process & 4.29 & 1 & 4.29 & 1353.78 & \\
Plasma gas flow rate & 1.33 & 2 & 0.66 & 209.016 & \\
Interaction & 0.098 & 2 & 0.049 & $15.45>$ & 3.55 \\
Residual & 0.057 & 18 & 0.0032 & & \\
& & & & & \\
Total & 5.77 & 23 & & & \\
\hline
\end{tabular}

Obs.: Index of significance $(\alpha)=5 \%$

Table 6. Results of analysis of variance for reinforcement. 


\begin{tabular}{lccccc}
\hline Source of variation & $\begin{array}{c}\text { Sum of } \\
\text { squares }\end{array}$ & $\begin{array}{c}\text { Degrees of } \\
\text { freedom }\end{array}$ & $\begin{array}{c}\text { Average of } \\
\text { squares }\end{array}$ & Fobserved & F critical \\
\hline Welding process & 8.35 & 1 & 8.354 & 5323.15 & \\
Plasma gas flow rate & 0.58 & 2 & 0.288 & 183.74 & \\
Interaction & 0.37 & 2 & 0.185 & $118.06>$ & 3.55 \\
Residual & 0.02825 & 18 & 0.00157 & & \\
& & & & & \\
Total & 9.33 & 23 & & & \\
\hline
\end{tabular}

Obs.: Index of significance $(\alpha)=5 \%$

Table 7. Results of analysis of variance for penetration.

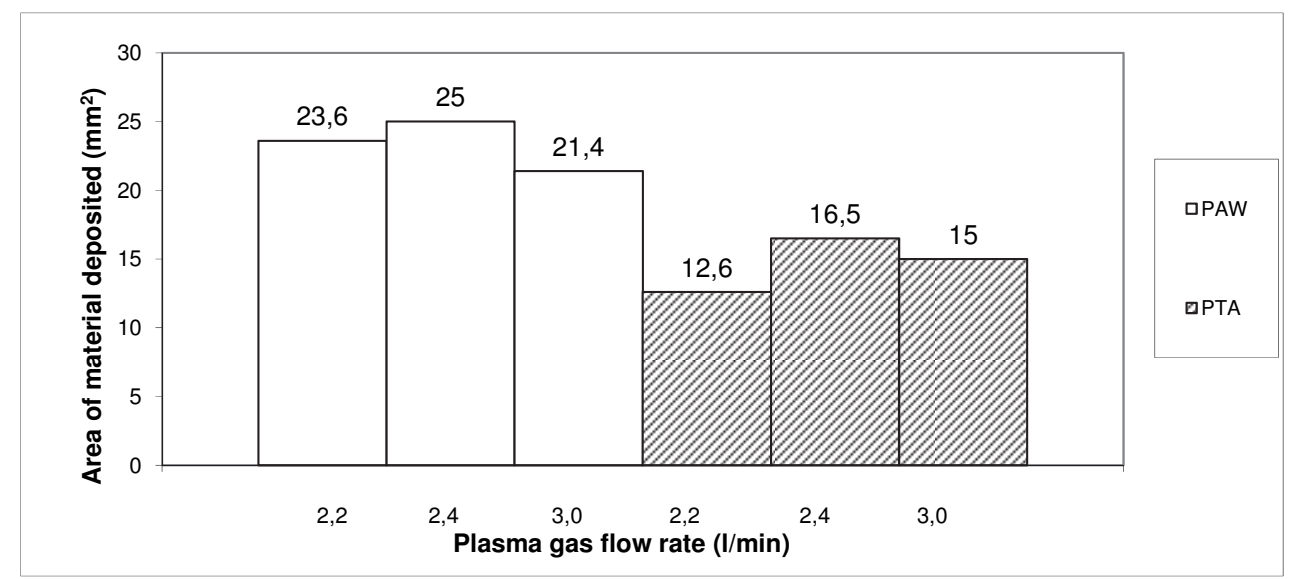

Fig. 11. Area of material deposited in PAW and PTA processes.

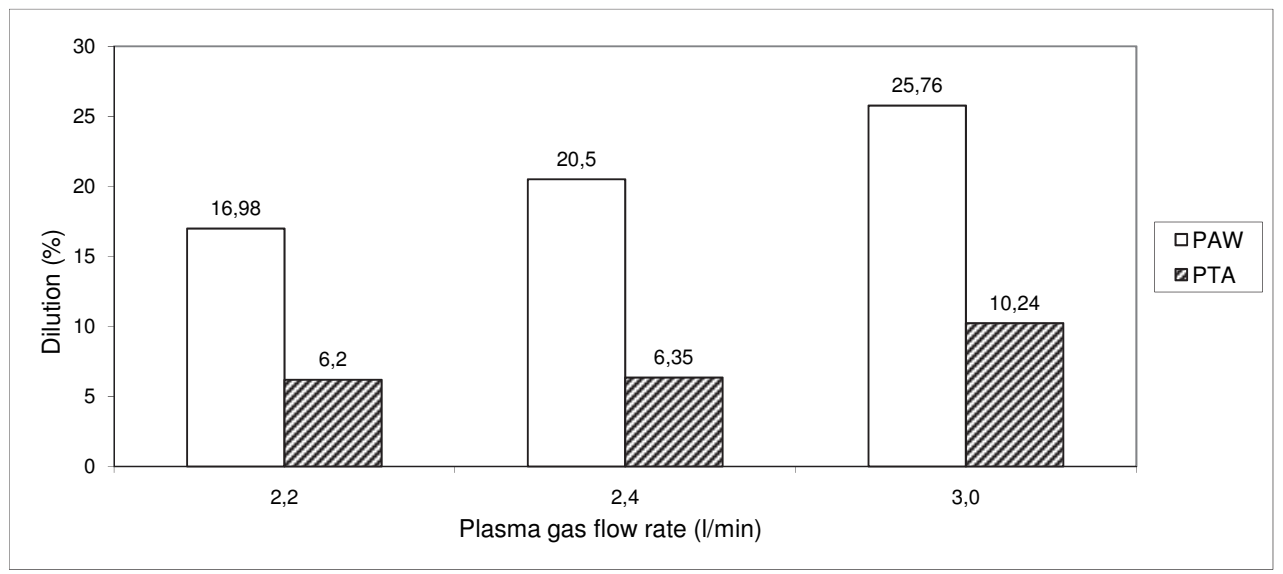

Fig. 12. Effect of plasma gas flow rate on degree of dilution in PAW and PTA processes. 


\begin{tabular}{lccccc}
\hline Source of variation & $\begin{array}{c}\text { Sum of } \\
\text { squares }\end{array}$ & $\begin{array}{c}\text { Degrees of } \\
\text { freedom }\end{array}$ & $\begin{array}{c}\text { Average of } \\
\text { squares }\end{array}$ & Fobserved & F critical \\
\hline Welding process & 1102.43 & 1 & 1102.43 & 25289.88 & \\
Plasma gas flow rate & 182.16 & 2 & 91.08 & 2089.39 & \\
Interaction & 25.93 & 2 & 12.96 & $297.4>$ & 3.55 \\
Residual & 0.785 & 18 & 0.044 & & \\
& & & & & \\
Total & 1311.305 & 23 & & & \\
\hline
\end{tabular}

Obs.: Index of significance $(\alpha)=5 \%$

Table 8. Results of analysis of variance for dilution

\subsection{Microhardness and microstructure}

Figure 13 shows the typical microstructures of the solidification in the center of the weld bead. When a plasma gas flow rate of $2.2 \mathrm{l} / \mathrm{min}$ was used in the PAW and PTA processes the microstructure was more refined. For a plasma gas flow rate of $3.01 / \mathrm{min}$ for both welding processes the microstructure was less refined.

The microhardness profiles evaluated along the cross-section of the deposits are shown in Figures 14 and 15 for the PAW and PTA processes, respectively.

The data in Figure 14 together with the analysis of variance in Table 9, related to the PAW process, indicate that, in general, the plasma gas flow rate significantly affects the hardness. On the other hand, the data in Figure 15 together with the analysis of variance in Table 10, which relate to the PTA process, indicate that the plasma gas flow rate does not significantly affect the hardness. Deposits obtained with the PAW process have lower hardness values, which is to be expected given the less refined structures and higher degrees of dilution.

\begin{tabular}{lccccc}
\hline Source of variation & $\begin{array}{c}\text { Sum of } \\
\text { squares }\end{array}$ & $\begin{array}{c}\text { Degrees of } \\
\text { freedom }\end{array}$ & $\begin{array}{c}\text { Average of } \\
\text { squares }\end{array}$ & Fobserved & F critical \\
\hline Plasma gas flow rate & 18214.93 & 2 & 9107.463 & $151.9637>$ & 3.2381 \\
Residual & 2337.341 & 39 & 59.93183 & & \\
& & & & & \\
Total & 20552.27 & 41 & & \\
\hline
\end{tabular}

Obs.: Index of significance $(\alpha)=5 \%$

Table 9. Results of analysis of variance for average hardness of microstructure - PAW. 

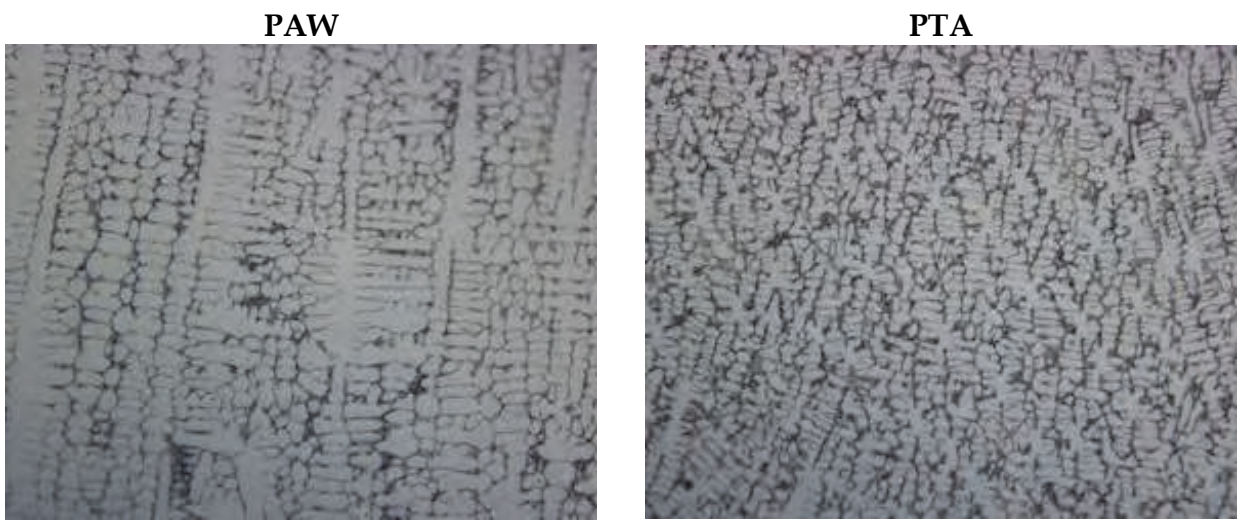

a) Plasma gas flow rate $=3.0(1 / \mathrm{min})$
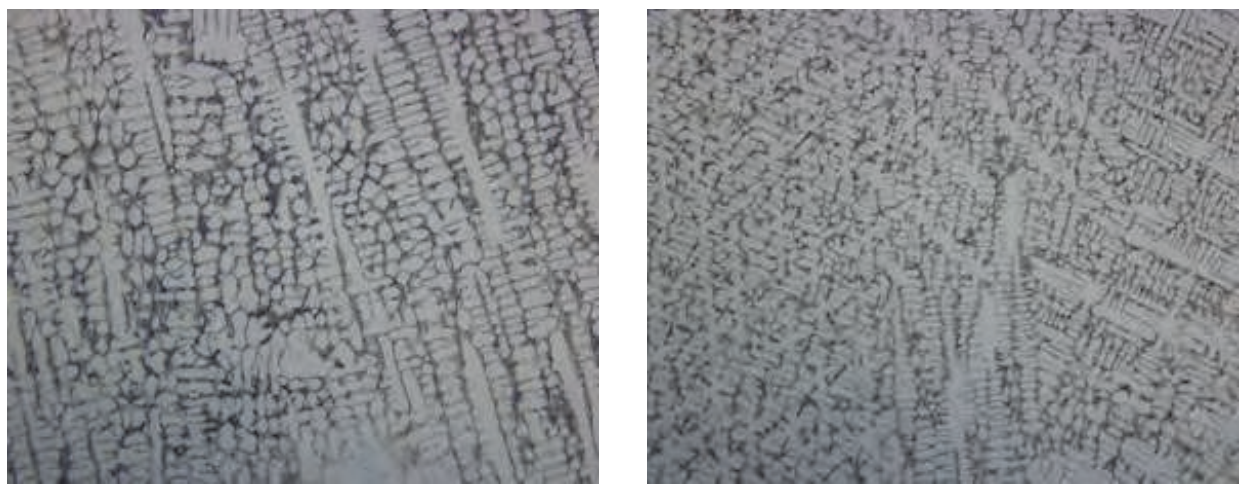

b) Plasma gas flow rate $=2.4(1 / \mathrm{min})$
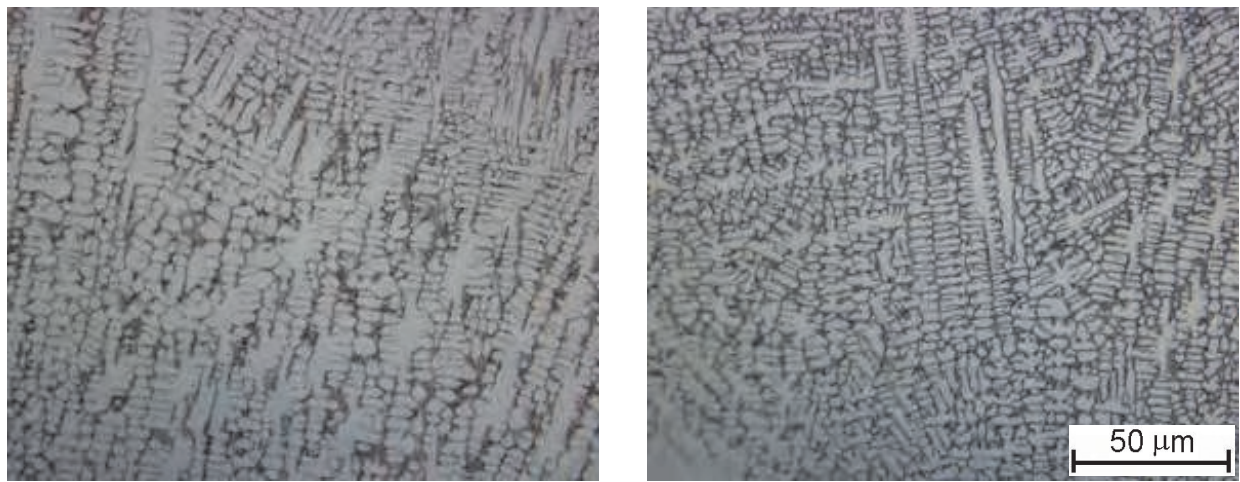

c) Plasma gas flow rate $=2.2(1 / \mathrm{min})$

Fig. 13. Micrographs of the samples of Stellite 6 for the PAW and PTA processes. Centre of weld bead. 


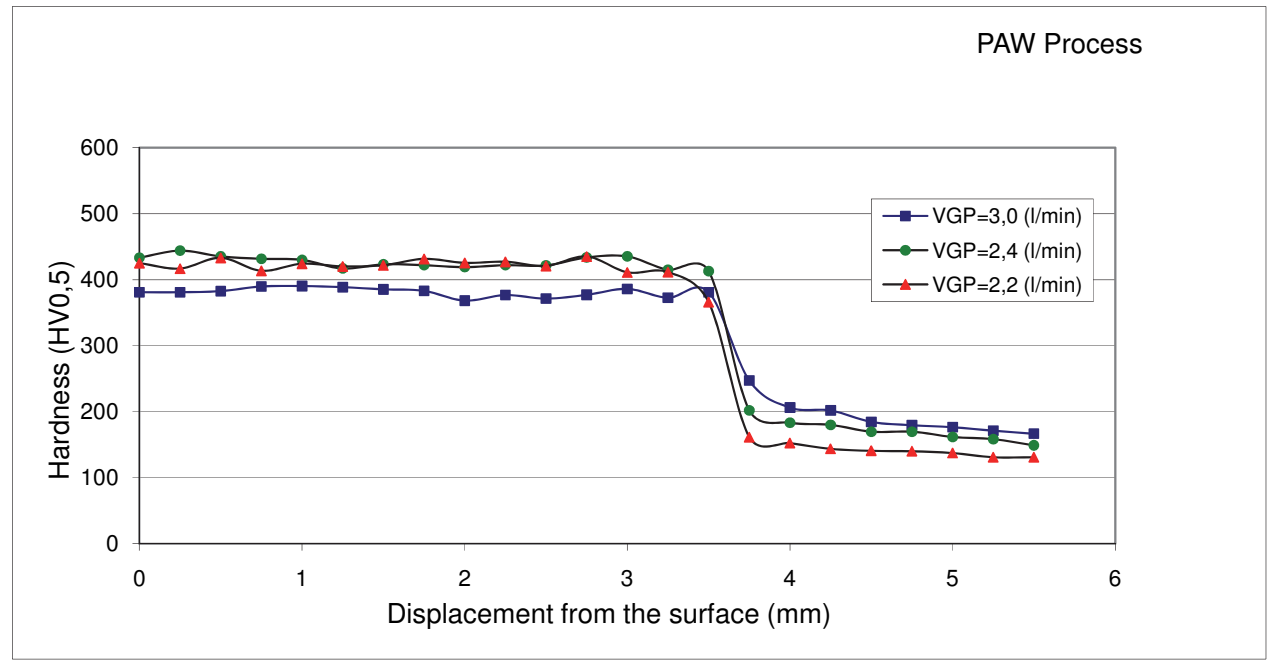

Fig. 14. Effect of plasma gas flow rate on hardness in PAW process.

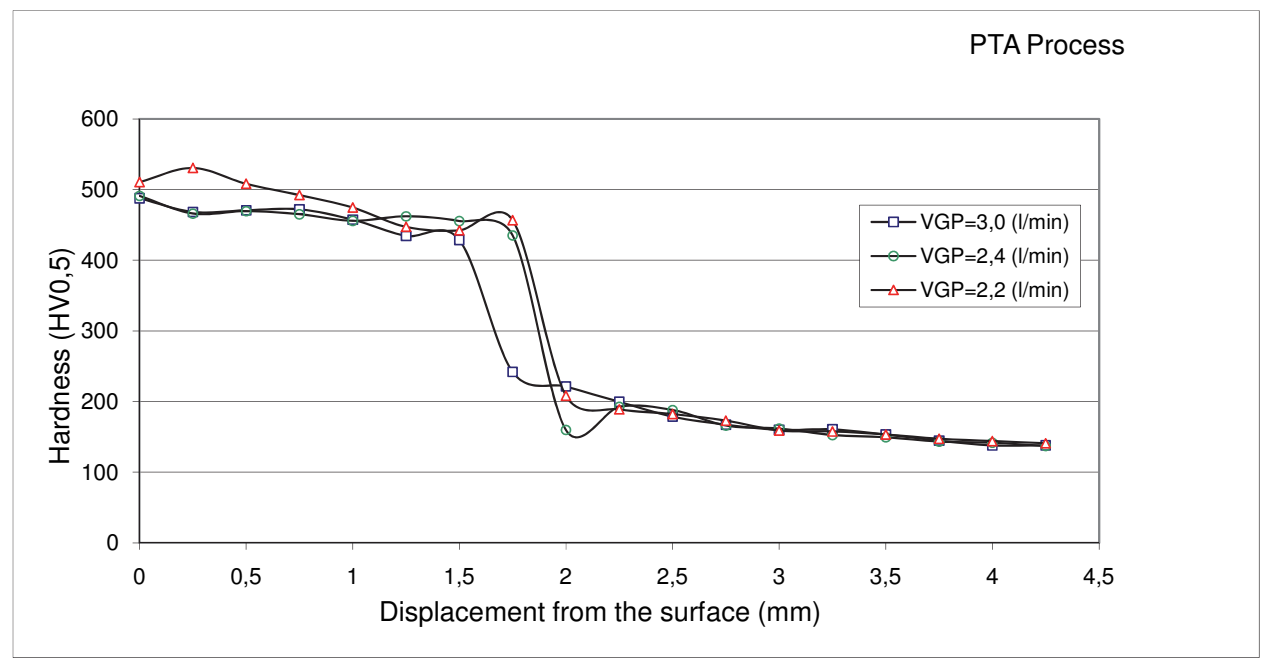

Fig. 15. Effect of plasma gas flow rate on hardness in PTA process. 


\begin{tabular}{lccccc}
\hline Source of variation & $\begin{array}{c}\text { Sum of } \\
\text { squares }\end{array}$ & $\begin{array}{c}\text { Degrees of } \\
\text { freedom }\end{array}$ & $\begin{array}{c}\text { Average of } \\
\text { squares }\end{array}$ & Fobserved & F critical \\
\hline Plasma gas flow rate & 2729.185 & 2 & 1364.593 & $2.388627<$ & 3.554561 \\
Residual & 10283.17 & 18 & 571.2875 & & \\
& & & & & \\
Total & 13012.36 & 20 & & & \\
\hline
\end{tabular}

Obs.: Index of significance $(\alpha)=5 \%$

Table 10. Results of analysis of variance for average hardness of microstructure -- PTA.

It was verified that the PTA process generates a more refined microstructure and consequently greater hardness than the PAW process, as also observed by Silvério (2003).

\section{Conclusions}

Based on the experimental results obtained in this study the conclusions are as follows:

- The PTA process produced a better surface finish and better wetting. Due to the deposition efficiency and the difference in the orifice diameter of the constrictor nozzle used in the welding processes studied the main results are:

- In the PTA process lower dilution values were achieved in comparison with the PAW process.

- Greater weld bead width was obtained using the PTA process.

- On comparing the deposits obtained through the two processes it could be observed that the reinforcement and penetration are always lower in the PTA process.

- Deposits obtained with the PAW process had lower hardness values as expected due to the less refined structures and higher degrees of dilution.

\section{References}

Dai, W. S.; Chen, L. H. \& Lui, T. S. (2001). $\mathrm{SiO}_{2}$ particle erosion of spheroidal graphite cast iron after surface remelting by the plasma transferred arc process. Available at: <http:/ / www.sciencedirect.com> Accessed in: Nov. 2008.

Gatto, A.; Bassoli, E. \& Fornari, M. Plasma Transferred Arc deposition of powdered high performances alloys: process parameters optimisation as a function of alloy and geometrical configuration. Available at:<http://www.sciencedirect.com> Accessed in: Jun. 2009.

Zhang, L.; Sun, D. \& Yu, H.(2008). Effect of niobium on the microstructure and wear resistance of iron-based alloy coating produced by plasma cladding. Available at:

<http://www.elsevier.com/locate/msea> Accessed in: Nov. 2008.

LIU, Y. F.; Mu, J. S. \& Yang, S. Z. (2007). Microstructure and dry-sliding wear properties of TiCreinforced composite coating prepared by plasma-transferred arc weld-surfacing process. Available at:<http://www.elsevier.com/locate/msea> Accessed in: Nov. 2008.

Oliveira, M. A. (2001). Estudo do processo plasma com alimentação automática de arame: 78p. Dissertação (Mestrado em Engenharia Mecânica)-Programa de Pós-Graduação em Engenharia Mecânica, UFSC, Florianópolis. 
Vergara, V. M. (2005). Inovação do equipamento e avaliação do processo plasma de arco transferido alimentado com pó (PTAP) para soldagem fora de posição: 2005. 174p. Doctoral Thesis, Mechanical Engineering Department - UFSC, Florianópolis.

Hallen, H.; Lugscheider, E.; Ait-Mekideche, A. Plasma transferred arc surfacing with high deposition rates. In: Proceedings of conference on thermal spray coatings: properties, processes and applications, Pittsburgh, USA, 4-10 May 1991. ASM International; 1992. p. 537-9.

SIlva, C. R.; Ferraresi, V. A \& Scotti, A. (2000). A quality and cost approach for welding process selection. J. Braz. Soc. Mech. Sci., Campinas, v. 22, n. 3. Available from $<$ http:/ / www.scielo.br/scielo.php?script=sci_arttext\&pid=S0100$73862000000300002 \& \operatorname{lng}=$ en\&nrm=iso>. Accessed on 29 Nov. 2009. doi: 10.1590/S0100-73862000000300002.

LIN, J. A. (1999). Simple model of powder catchment in coaxial laser cladding. Optics \& Laser Technology, 233-238.

Davis, J. R. - Davis and Associates. (1993). Hardfacing, Weld Cladding and Dissimilar Metal Joining. In: ASM Handbook - Welding, Brazing and Soldering, Vol. 6. 10th ed. OH: ASM Metals Park. p. 699-828.

Silvério, R. B. \& D'Oliveira , A.S. C. M. Revestimento de Liga a Base de Cobalto por PTA com Alimentação de Pó e Arame. In: Congresso Brasileiro de Engenharía de Fabricação, Uberlândia-MG, Maio. 2003. 


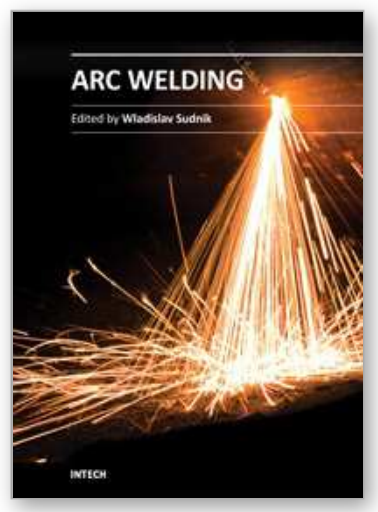

\author{
Arc Welding \\ Edited by Prof. Wladislav Sudnik
}

ISBN 978-953-307-642-3

Hard cover, 320 pages

Publisher InTech

Published online 16, December, 2011

Published in print edition December, 2011

Ever since the invention of arc technology in 1870s and its early use for welding lead during the manufacture of lead-acid batteries, advances in arc welding throughout the twentieth and twenty-first centuries have seen this form of processing applied to a range of industries and progress to become one of the most effective techniques in metals and alloys joining. The objective of this book is to introduce relatively established methodologies and techniques which have been studied, developed and applied in industries or researches. State-of-the-art development aimed at improving technologies will be presented covering topics such as weldability, technology, automation, modelling, and measurement. This book also seeks to provide effective solutions to various applications for engineers and researchers who are interested in arc material processing. This book is divided into 4 independent sections corresponding to recent advances in this field.

\title{
How to reference
}

In order to correctly reference this scholarly work, feel free to copy and paste the following:

Victor Vergara Diaz, Jair Carlos Dutra and Ana Sofia Climaco D'Oliveira (2011). Hardfacing by Plasma Transferred Arc Process, Arc Welding, Prof. Wladislav Sudnik (Ed.), ISBN: 978-953-307-642-3, InTech, Available from: http://www.intechopen.com/books/arc-welding/hardfacing-by-plasma-transferred-arc-process

\section{INTECH}

open science | open minds

\section{InTech Europe}

University Campus STeP Ri

Slavka Krautzeka 83/A

51000 Rijeka, Croatia

Phone: +385 (51) 770447

Fax: +385 (51) 686166

www.intechopen.com

\author{
InTech China \\ Unit 405, Office Block, Hotel Equatorial Shanghai \\ No.65, Yan An Road (West), Shanghai, 200040, China \\ 中国上海市延安西路65号上海国际贵都大饭店办公楼405单元 \\ Phone: +86-21-62489820 \\ Fax: +86-21-62489821
}


(C) 2011 The Author(s). Licensee IntechOpen. This is an open access article distributed under the terms of the Creative Commons Attribution 3.0 License, which permits unrestricted use, distribution, and reproduction in any medium, provided the original work is properly cited. 